\title{
Innovation on the Open Sea: Examining Competence Transfer and Open Innovation in the Design of Offshore Vessels
}

\author{
Odd Jarl Borch and Marina Z. Solesvik
}

\author{
'C The sea! the sea! the open sea! \\ The blue, the fresh, the ever free! \\ Bryan W. Procter \\ (Barry Cornwall) (1787-1874) \\ Poet and solicitor
}

1)

\begin{abstract}
In this article, we discuss the role of open innovation in collaborative design processes in mature industries such as the shipping industry. We examine the design of high-tech offshore service vessels in environments characterized by high volatility and complexity. We elaborate on the role that accumulating and sharing core competences plays in speeding up the innovation process and increasing product value. We present a longitudinal case study of a shipping company implementing an open innovation approach that integrates its own core competences in offshore operations with the competences of ship designers and ship builders to develop a new design for challenging environments. In this article, we draw on an open innovation approach and a competence-based view to demonstrate how the firm can "reach out" to gain novel competences related to innovation, which may transform the competitive environment to the firm's advantage. The article would be useful to innovation scholars and practitioners who work with innovative product development.
\end{abstract}

\section{Introduction}

New product development and design are expensive, risky, and resource-intensive processes (Parker, 2000). The role of innovation in new product development and design is significant (Veryzer, 1998), and success is often a result of a collaborative effort (Kotabe \& Swan, 1995; Solesvik, 2011). Modern firms, especially small and medium-sized enterprises, often cannot afford to have all necessary $R \& D$ competences in-house. Thus, they actively involve product users and other stakeholders in new product and new design development through open innovation processes (Piller \& Walcher, 2006).

Open innovation was conceptualized relatively recently (Chesbrough, 2002), but it has rapidly become a popular approach to new product development. Open innovation is defined as "the use of purposive inflows and outflows of knowledge to accelerate internal innovation, and expand the markets for external use of innovation, respectively" (Chesbrough, 2006). There are many approaches and dimensions to open innovation, but for the purposes of this study, we focus on the importance of tight cooperation between the end user and suppliers of core production units.

Opening up an organization to allow partner access to inner competences is a challenging strategic issue. The idea of core competence (Prahalad \& Hamel, 1990) was theorized by Hamel and Heene (1994), Sanchez, Heene, and Thomas (1996), Sanchez (2004), and Freiling (2004), who collectively developed the competencebased view into a new strategic management perspective. Several definitions of firm competence have been proposed, but for the purpose of this study, we use the definition proposed by Sanchez, Heene, and Thomas (1996), who view a core competence as "a resource that increases the ability to sustain the coordinated deployment of assets in a way that helps a firm achieve its goals." 


\section{Competence Transfer and Open Innovation in the Design of Offshore Vessels}

\section{Odd Jarl Borch and Marina Z. Solesvik}

Prior research into the competence-based view suggests that a firm as an open system might link firm-addressable resources, capabilities and competences in collaborative networks in order to respond to quickly changing market opportunities (Sanchez, 2004). Moreover, Sanchez and colleagues (1996) noted that:

"To have access to resources that are under the control of other firms but that are useful in pursuing its own goals, a firm may bid for use of other firms' competences or resources in market transactions, or may enter into competence alliances to connect its competences and resources with those of other firms."

The competence-based view distinguishes between competence leveraging and competence building. The former activity applies a firm's existing competences in existing or new markets without qualitative changes in the existing kinds of asset stocks and flows (Sanchez et al., 1996). The competence-based approach recognizes that a firm can leverage firm-specific and firm-addressable resources and competences to achieve goals and competitive advantage (Easton \& Araujo, 1996). Firmaddressable competences can be obtained through market transactions or through collaboration with other firms. Child, Faulkner, and Tallman (2005) argue that, in a network, members have immediate access to necessary competences without the need to invest in developing these competences internally. However, this openness comes with a risk of sharing core competence with others without receiving the expected benefits in return, and there may be costs due to adaptations in resource configuration within the firm during the alliance. The latter activity, competence building, implies qualitative changes in the existing asset stocks and flows as well as abilities to coordinate and deploy new and existing assets in order to achieve the firm's goals (Metzenthin, 2005). Competence building influences the industry dynamics: firms identify and seek to change desirable qualitative changes in stocks and flows of assets through learning (Post, 1997).

The competence-based view postulates that firms strive to leverage competences to fulfil their ambitions. Durand (1997) has suggested that there is both a static and a dynamic mode to accumulating competence. The static modes relate to reinforcement and synergistic fit related to present competences. The dynamic modes include access to new knowledge through new network access and adapting the organization to others through alliances (Sanchez et al., 1996). However, diffusion of resources and competences due to interfirm collaboration might be difficult because firms often fail to develop a common alliance strategy (Freiling, 2004). This mode can be costly, and some firms are reluctant to share desirable competences with other firms. Thus, the firm has to be careful when selecting partners; it must have a clear picture of its ambitions and the core competences involved in the cooperative process. And, it must take care to safeguard its own resources throughout the process.

In this article, we apply the competence-based view to the field of ship design and shipbuilding, which has joined the global trend towards open innovation approaches (Solesvik \& Gulbrandsen, 2013). In the next section, we present and briefly analyze an illustrative case from a Norwegian offshore shipping company that has recently built an innovative offshore vessel for the High Arctic using a collaborative approach including competence transfer and open innovation. We examine the case in light of the open innovation perspective and the competence-based view, with an emphasis on their importance to companies developing products for highly volatile and complex environments.

\section{Illustrative Case: Offshore Shipping in the High Arctic}

The Arctic contains as much as $25 \%$ of the remaining oil and gas resources in the world. The High Arctic encompasses the regions north of the Arctic Circle where cold weather may cause severe ice and icing conditions. It includes Alaska, northeastern Canada, the Greenland coast, the Barents Sea, northern and eastern Russia, and the North East Passage (i.e., the Northern Sea Route) through northern Russia. The centre of gravity for Norwegian petroleum activities is moving gradually north into the Norwegian Sea, the Barents Sea, and the rest of what is termed Arctic waters. Operations in this region require vessels that are tailor-made for a harsh climate and an area with limited infrastructure. These conditions call for vessels with ice-strengthening and a high degree of functionality, and they must be well equipped for multi-purpose action.

Simon Møkster Shipping AS (mokster.no) is an offshore shipping company located in Stavanger, the oil capital of Norway. Captain Simon Møkster established the company in 1968, and the company is still owned and managed by the Møkster family. The company owns 25 offshore vessels. There are 665 employees in the company, 32 work in the main office, and the rest of employees work at sea. However, although many Norwegian offshore shipping companies operate both in the Norwegian offshore sector and worldwide, Simon 


\section{Competence Transfer and Open Innovation in the Design of Offshore Vessels}

\section{Odd Jarl Borch and Marina Z. Solesvik}

Møkster Shipping AS decided only to develop their operations alongside the Norwegian coast, one of the most challenging sea areas in the world. They focused on adding competence on operating in the conditions found in the High Arctic.

Recently, the company wanted to win contracts to support offshore oil and gas operations in the Goliath field in the Barents Sea with stand-by vessel and emergency response and rescue vessels. The conditions for offshore operations in the Barents Sea are different from the familiar conditions of the North Sea. The conversion of standard offshore vessels to ice-class vessels and equipping them with the winterization package is not the optimal solution (Berg et al., 2012). Thus, the company's management decided to invest into the fleet of tailor-made vessels for the Arctic. Given that the Arctic market is quite new and such ships have not been developed before by Norwegian designers, the design needed to be very innovative in terms of functionality, capacity, and environmentally friendly operation. There were two innovation options in the purchase phase: i) order a complete new project from a ship design company and not be involved into the innovation development process or ii) engage in open innovation and be an active participant in the R\&D process. The shipping company opted for the latter opportunity even though it had a small administration staff with limited capacity.

The shipping company decided to cooperate with a ship design and shipbuilding company to develop a tailor-made vessel, and they evaluated several candidate design companies. Due to technology newness and the lack of $R \& D$ in this area, the company searched for partners that could understand every aspect of the value chain including designing, building, equipping, and running this type of vessel. Finally, the VARD company (vard.com) was selected to develop and build the vessel that would support operations of the oil company ENI (eninorge.com/en/). VARD unites a ship design firm and a shipyard in the same corporation, in addition to offering equipment and industry services.

The shipping company contributed their top-level competence including the CEO, CTO, and operation management, while closely following the process and scrutinizing the suggestions from the design company. They involved their most experienced operative personnel, bringing them to shore from their vessels to work on the details. The operating personnel, together with middle management, cooperated tightly with the designers to bring the different units together. Informa- tion was constantly exchanged between partners, and the designers had to reveal their knowledge as to best practice in the field and the limitations of different constructions. Not only the technical aspects had to be considered during the process: the cost of building and running the vessels was a critical issue. The financial and operating staff had to be included and the designers, the yard, and the equipment producers were confronted with functionality and cost issues.

One challenge was to learn what details the oil company would demand. The oil company participated marginally in the new vessel development due to market rules as to open competition. However, there was a systematic evaluation of data from other contracts with oil companies and the tacit knowledge acquired by senior staff and vessel management. After the first stage of development, an offer was given to the oil company on time with the necessary specifications. The Simon Møkster Shipping company competed with several other concepts, but won due to functionality details and environmental friendliness in combination with a competitive price. The new advanced vessel with unique characteristics was delivered to its new owners in 2015.

\section{Analysis}

The case discussion illustrates how a shipping company became involved in the open innovation process by first choosing a design partner with broad value chain insight and then taking part in the entire process of design and development with their own staff. In this case, an important factor for involving a company in open innovation was the lack of knowledge about market characteristics and customer needs. The context of the High Arctic is specific and little expertise had been accumulated in the area of offshore operations in the High Arctic with harsh weather conditions and long distances to the shore. Simon Møkster Shipping brought in their most experienced personnel to interact with the designer and refine the tacit operational knowledge into formalized knowledge related to the functionality of the vessel and to have the necessary tailor-made functionality guaranteed. These activities included a timeconsuming representation at the shipyard following the building process, with two or three staff members at the site in constant dialogue with the different sub-contractors and installations. Second, there were customer demands to consider. In this industry, the oil companies continuously look for vessels with increased productivity, safety, and efficiency. The competition in this mature market with several large suppliers is fierce. One of the ways to win a competitive game is to be one 


\section{Competence Transfer and Open Innovation in the Design of Offshore Vessels}

\section{Odd Jarl Borch and Marina Z. Solesvik}

step ahead of rivals. Innovativeness, achieved here by reaching out of the firm's boundaries to obtain market context competence from crew and shore staff, is an important factor that can help firms gain competitive advantage.

Many companies prefer to concentrate on their own core competences (Borch \& Solesvik, 2013, 2014). Simon Møkster Shipping decided to share their core competence with the cooperating design, equipment, and construction companies. This activity is in line with the findings of recent research that stresses the popularity of a multi-firm network organizational form in contemporary business (Fjeldstad et al., 2012). According to the multi-firm network concept, firms concentrate on their core competences and collaborate with other firms to obtain the other firms' core competences and thereby achieve the project's goals.

In the case of Simon Møkster Shipping AS, the company brought both their strategic apex and highly competent middle management staff into the process to a much larger degree than most of their competitors. The company contributed with the expertise of its employees in Arctic waters operations, and was creative in their price and contract strategy towards ENI as their customer. Simon Møkster Shipping then succeeded in not only emphasizing the technological innovation, but also innovation related to management and marketing. The management group of the firm supported intra-firm collaboration by collecting feedback from the sea personnel related to operations in the Arctic seas and about which construction features should be taken into account in the design phase. The company shared the salaries and scarce time of key personnel with the ship designers and yard personnel. In return, the shipping company employees involved in this open innovation project acquired new insight on complex construction under uncertainty, and gained the designer's knowledge about their competitors' best practice. Some other firms and organizations shared their competences as well, including the classification society, equipment suppliers, and others. This connection may take a formal contract approach with loose couplings or it may become a long-term partnership with strong ties based on trust and reciprocal exchange as in cluster thinking. In this case, strong cluster mechanisms were present in the region, which served as a platform for specific cooperative arrangements. As suggested by the competence-based view, firms can "reach out" and develop their competences if necessary. In this case, collaboration using an open innovation approach helped the shipping company to overcome its liability of smallness to develop a competitive edge in $R \& D$ and innovation.

\section{Conclusions and Implications}

In this article, we have emphasized the importance of collaborative efforts in new product development. Consistent with Jennings and colleagues (2015), modern design is a critical element of competitive advantage. An open innovation approach, where research and development efforts are undertaken in close reciprocal relationships with external providers, allows for the unification of core competences from different actors and increases the speed and quality of new product development. One important finding is that the firm has to gather significant core competence in their own organization and bring this into the process of development when collaborating with cooperating institutions. This may represent large (sunk) costs and a high risk of losing strategic knowledge if the company does not succeed in winning customers and contracts.

We added to the knowledge base by combining the open innovation perspective and the competencebased view. Both perspectives seek to explain the process of resource accumulation and inventions to increase the competitive advantage of a firm. We show in this article how the competence-based approach may help the firm to "reach out" to gain novel competences, which may transform the competitive environment to a firm's advantage. Furthermore, participation in joint $R \& D$ lifts the competences of firms to a higher level faster (Reiling, 2004).

The article raises new questions about how competences influence the aspects of open innovation activities, notably the rationale to enter into an open innovation agreement, partner evaluation and selection, and termination of the open innovation collaboration. Practitioners from the maritime industry and from other industries can use the information presented in this article when they elaborate the collaboration processes related to new product design and development. In particular, the presented case illustrates how firms can unite their competences with other firms and participate more actively in collaborative design, thereby avoiding buying off-the-shelf goods where competition is harsh. New trends in the industry, increasing complexity of operations (Borch \& Batalden, 2014), and very special requirements regarding tailormade production units for the different purposes enforce broader participation of the companies' specialists in the development of innovative products. 


\section{Competence Transfer and Open Innovation in the Design of Offshore Vessels}

\section{Odd Jarl Borch and Marina Z. Solesvik}

\section{About the Authors}

Odd Jarl Borch is a Professor of Strategy and Business Development at the University of Nordland in Bodø, Norway, and he is a Senior Researcher at Nordland Research Institute, also in Bodø. His research fields include corporate strategy, business development, innovation and entrepreneurship. Odd Jarl has published extensively in national and international journals and has broad teaching experience in addition to his comprehensive academic writings.

Marina Z. Solesvik is a Professor of Innovation and Management at the Stord/Haugesund University College in Norway. She also holds part-time positions in Norway as Professor at the University of Tromsø, the University of Nordland, and Bergen University College. She is a board member at several Norwegian firms and organizations, including the National Riksteatret in Oslo. Marina holds a PhD in Management from the Graduate Business School at the University of Nordland and a PhD in Entrepreneurship from the Institute of Agrarian Economy in Kiev, Ukraine. Her research interests include regional innovation, open innovation, maritime business, entrepreneurial intentions, female entrepreneurship, strategic alliances, and Arctic research.

\section{References}

Berg, T. E., Berge, B. O., Borgen, H., \& Hänninen, S. 2012. Intervention Vessel for Barents Sea Operation. In Proceedings of the American Society of Mechanical Engineers (ASME) 2012 31st International Conference on Ocean, Offshore and Arctic Engineering: 571-578.

Borch, O. J., \& Solesvik, M. Z. 2013. Collaborative Design of Advanced Vessel Technology for Offshore Operations in Arctic Waters. In Y. Luo (Ed.), Cooperative Design, Visualization, and Engineering: Proceedings of the 10th International CDVE Conference: 157-160. Berlin: Springer Berlin Heidelberg. http://dx.doi.org/10.1007/978-3-642-40840-3

Borch, O. J., \& Batalden, B.-M. 2014. Business-Process Management in High-Turbulence Environments: The Case of the Offshore Service Vessel Industry. Maritime Policy \& Management: 42(5): $1-18$.

http://dx.doi.org/10.1080/03088839.2014.913816

Borch, O. J., \& Solesvik, M. 2014. Partner Selection for Innovation Projects. Paper presented at the International Society for Professional Innovation Management (ISPIM) Americas Innovation Forum 2014, Montreal, Canada, 5-8 October, 2014.

Chesbrough, H. W. 2002. Making Sense of Corporate Venture Capital. Harvard Business Review, 80(3): 90-99.
Chesbrough, H. W. 2006. Open Business Models: How to Thrive in the New Innovation Landscape. Boston: Harvard Business School Press.

Child, J., Faulkner, D., \& Tallman, S. B. 2005. Cooperative Strategy: Managing Alliances, Networks, and Joint Ventures. Oxford: Oxford University Press.

Durand, T. 1997. Strategizing for Innovation: Competence Analysis in Assessing Strategic Chance. In A. Heene \& R. Sanchez (Eds.), Competence-Based Strategic Management: 127-150. Chichester, UK: John Wiley \& Sons Ltd.

Easton, G., \& Araujo, L. 1996. Characterizing Organizational Competences: An Industrial Networks Approach. In R. Sanchez, A. Heene, \& H. Thomas. (Eds.), Dynamics of Competence-Based Competition: Theory and Practice in the New Strategic Management: 183-207. Oxford: Elsevier.

Fjeldstad, Ø. D., Snow, C. C., Miles, R. E., \& Lettl, C. 2012. The Architecture of Collaboration. Strategic Management Journal, 33(6): 734-750.

http://dx.doi.org/10.1002/smj.1968

Freiling, J. 2004. A Competence-Based Theory of the Firm. Management Revue, 15(1): 27-52.

Gruber, M., De Leon, N., George, G., \& Thompson, P. 2015. Managing by Design. Academy of Management Journal, 58(1): 1-7. http://dx.doi.org/10.5465/amj.2015.4001

Hamel, G., \& Heene, A. 1994. Competence-Based Competition. Chichester, UK: John Wiley \& Sons Ltd.

Jennings, J. E., Edwards, T., Jennings, P. D., \& Delbridge, R. 2015. Emotional Arousal and Entrepreneurial Outcomes: Combining Qualitative Methods to Elaborate Theory. Journal of Business Venturing, 30(1): 113-130.

http://dx.doi.org/10.1016/j.jbusvent.2014.06.005

Kotabe, M., \& Swan, K. S. 1995. The role of strategic alliances in hightechnology new product development. Strategic Management Journal, 16(8): 621-636. http://dx.doi.org/10.1002/smj.4250160804

Metais, E., \& Meschi, P.-X. 2005. Competence-Based Management and Strategic Flexibility: The Case of Air Liquide. In R. Sanchez \& A. Heene (Eds.), Competence Perspectives on Managing Internal Processes: 91-110. Amsterdam: Elsevier.

Metzenthin, R. 2005. Mergers and Acquisitions as Gap-Closing Activities in Competence Building and Leveraging. In R. Sanchez \& A. Heene (Eds.), Competence Perspectives on Managing Internal Processes: 129-150. Amsterdam: Elsevier.

Parker, H. 2000. Interfirm Collaboration and the New Product Development Process. Industrial Management \& Data Systems, 100(6): 255-260. http://dx.doi.org/10.1108/02635570010301179

Piller, F. T., \& Walcher, D. 2006. Toolkits for Idea Competitions: A Novel Method to Integrate Users in New Product Development. R\&D Management, 36(3): 307-318. http://dx.doi.org/10.1111/j.1467-9310.2006.00432.x

Post, H. A. 1997. Building a Strategy on Competences. Long Range Planning, 30(5): 733-740. http://dx.doi.org/10.1016/S0024-6301(97)00049-6

Prahalad, C. K., \& Hamel, G. 1990. The Core Competence of the Corporation. Harvard Business Review, (May/June): 79-91. 


\section{Competence Transfer and Open Innovation in the Design of Offshore Vessels}

\section{Odd Jarl Borch and Marina Z. Solesvik}

Sanchez, R. 2004. Understanding Competence-Based Management: Identifying and Managing Five Modes of Competence. Journal of Business Research, 57(5): 518-532.

http://dx.doi.org/10.1016/S0148-2963(02)00318-1

Sanchez, R., Heene, A., \& Thomas, H. 1996. Towards the Theory and Practice of Competence-Based Competition. In R. Sanchez, A. Heene, \& H. Thomas (Eds.), Dynamics of Competence-Based Competition: Theory and Practice in the New Strategic Management: 1-35. Oxford: Elsevier.

Solesvik, M. 2011. Collaborative Knowledge Management: Case Studies from Ship Design. International Journal of Business Information Systems, 8(2): 131-145.

http://dx.doi.org/10.1504/IJBIS.2011.041788
Solesvik, M. Z., \& Gulbrandsen, M. 2013. Partner Selection for Open Innovation. Technology Innovation Management Review, 3(4): 11-16.

http://timreview.ca/article/674

Teece, D. J., Pisano, G., \& Shuen, A. 1997. Dynamic Capabilities and Strategic Management. Strategic Management Journal, 18(7): 509-533.

http://dx.doi.org/10.1002/(SICI)1097-0266(199708)18:7<509::AIDSMJ882>3.0.CO;2-Z

Veryzer, R. W. 1998. Discontinuous Innovation and the New Product Development Process. Journal of Product Innovation Management, 15(4): 304-321. http://dx.doi.org/10.1111/1540-5885.1540304

Citation: Borch, O. J., \& Solesvik, M. Z. 2015. Innovation on the Open Sea: Examining Competence Transfer and Open Innovation in the

Design of Offshore Vessels. Technology Innovation Management Review, 5(9): 17-22. http://timreview.ca/article/926

(cc) BY

Keywords: open innovation, core competencies, cooperative design, shipbuilding, Arctic, offshore operations 